\title{
THE CORRELATIONS AMONG SEVERITY OF DEPRESSION, LEVEL OF OBSERVED EXPRESSED EMOTIONS, PERCEIVED SOCIAL SUPPORT AND PSYCHOSOCIAL FUNCTIONING IN PATIENTS WITH UNIPOLAR DEPRESSION
}

Nevena Igrutinovic ${ }^{1,2}$, Borjanka Batinic ${ }^{3,4}$ and Goran Mihajlovic ${ }^{5,6}$

${ }^{1}$ Clinical Centre of Kragujevac, Clinic of Pediatrics, Kragujevac, Serbia

${ }^{2}$ University of Kragujevac, Faculty of Medical Sciences, Kragujevac, Serbia ${ }^{3}$ Clinical Centre of Serbia, Clinic of Psychiatry, Belgrade, Serbia

${ }^{4}$ University of Belgrade, Faculty of Philosophy, Department of Psychology, Belgrade, Serbia ${ }^{5}$ Clinical Centre of Kragujevac, Clinic of Psychiatry, Kragujevac, Serbia

${ }^{6}$ University of Kragujevac, Faculty of Medical Sciences, Department of Psychiatry, Kragujevac, Serbia

\author{
KORELACIJE IZMEĐU IZRAŽENOSTI DEPRESIJE, NIVOA \\ OPAŽENIH EKSPRESIJA EMOCIJA, DOŽIVLJENE SOCIJALNE \\ PODRŠKE I PSIHOSOCIJALNOG FUNKCIONISANJA KOD \\ PACIJENATA SA UNIPOLARNOMI DEPRESIJOM

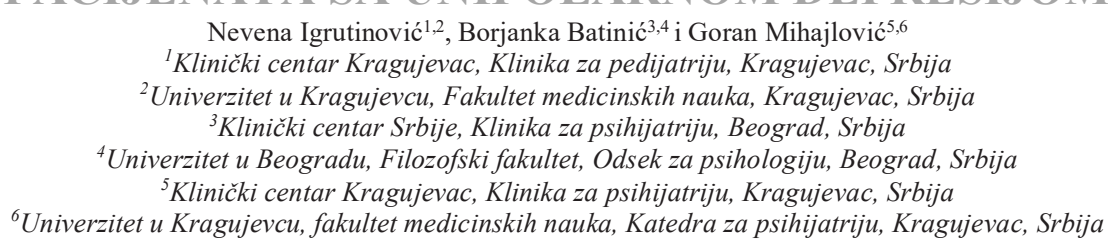

\begin{abstract}
The aims of the study were to examine the correlations among severity of depression, level of psychosocial functioning, level of observed expressed emotions and perceived social support in patients diagnosed with unipolar depression. The sample included 61 patients. The following study instruments were applied: the Beck Depression Inventory II, the Functioning Assessment Short Test, the Level of Expressed Emotion scale and the Multidimensional Scale of Perceived Social Support. Descriptive statistics of the sample have shown the mean age of 42.39 years $(S D=13.387)$, moderate severity of depression $(A S=22.7, S D=11.984)$, moderate level of observed expressed emotions (AS=74.70, $S D=17.959)$, moderate level of psychosocial difficulties $(A S=26.33, S D=17.207)$ and high level of perceived social support $(A S=5.24, S D=1.395)$. There were significant positive correlations between severity of depression and psychosocial difficulties $(r=0.69)$ and perceived social support $(r=-0.42)$, as well as between psychosocial difficulties and both levels of observed expressed emotions $(r=0.31)$ and perceived social support $(r=-$ 0.53). Hierarchical multiple regression analysis showed that $47.1 \%$ of the psychosocial functioning variance can be predicted by severity of depressive symptoms, and perceived social support explained the additional 7\% of variance. The level of observed expressed emotion didn't show an additional explanation of the psychosocial functioning variance. Our research showed that the severity of depressive symptoms and perceived social support predict difficulties in psychosocial functioning, while the level of observed expressed emotion was not an important predictor.
\end{abstract}

Keywords: unipolar depression, psychosocial functioning, level of observed expressed emotions, perceived social support.

DOI: 10.2478/sjecr-2020-0048

\section{SAŽETAK}

Cilj istraživanja bio je ispitati korelacije između izraženosti depresije, nivoa psihosocijalnog funkcionisanja, nivoa opaženih ekspresija emocija i doživljene socijalne podrške kod pacijenara sa dijagnozom unipolarne depresije. Uzorak je obuhvatio 61 pacijenta. Korišćeni su sledeći upitnici: Bekov inventar depresivnosti, Kratak upitnik procene funkcionalnosti, Upitnik o nivou emocionalne ekspresije i Multidimenzionalna skala doživljene socijalne podrške. Deskriptivna statistička analiza uzorka pokazala je prosečan uzrast od 42.39 godina $(S D=13.387)$, umerenu izraženost depresije $(A S=22.7, S D=11.984)$, umereni nivo opažene ekspresije emocija $(A S=74.70, S D=17,959)$, umereni nivo teškoća u psihosocijalnom funkcionisanju (AS=26.33, $S D=17.207)$ i visoki nivo doživljene socijalne podrške $(A S=5.24$, $S D=1.395$ ). Pokazane su značajne pozitivne korelacije između izraženosti depresije i teškoća u psihosocijalnom funkcionisanju $(r=0.69) i$ doživljene socijalne podrške $(r=-0.42)$, kao i između teškoća u psihosocijalnom funkcionisanju i nivoa opažene ekspresije emocija $(r=0.31)$ i doživljene socijalne podrške $(r=-0.53)$. Primenom hijerarhijske multiple regresije pokazano je da $47.1 \%$ varijanse psihosocijalnog funkcionisanja može biti predviđen izraženošću depresivnih simptoma, dok doživljena socijalna podrška objašnjava dodatnih 7\% varijanse. Nivo opažene ekspresije emocija nije doprineo dodatnom objašnjenju varijanse psihosocijalnog funkcionisanja. Naše istraživanje pokazalo je da izraženost depresivnih simptoma i doživljena socijalna podrška predviđaju teškoće u psihosocijalnom funkcionisanju, dok nivo opažene ekspresije emocija nije značajan prediktor.

Ključne reči: unipolarna depresija, psihosocijalno funkcionisanje, nivo opažene ekspresije emocija, doživljena socijalna podrška.

Corresponding author: Nevena Igrutinović University of Kragujevac, Faculty of Medical Sciences -mail:niblackpearl@gmail.com Postal address: 6, Pešterska 34000 


\section{INTRODUCTION}

Depressive disorders are considered to be one of the most important health problems, due to their prevalence, recurrent or chronic course, negative impact on the quality of life, risk of suicide and frequent comorbidity with other mental disorders and physical illnesses (1). Depressive disorders are manifested through depressed mood, a decrease in hedonia, problems with sleep and appetite, concentration problems, feelings of guilt, low self-esteem and lack of energy and will(1).

Many studies have examined the relationship between depression and recognition of facial emotion, and some of them have concluded that depressed people have difficulties in identifying all the basic emotions except sorrow (2). However, few studies have investigated the relationship between depression and level of observed expressed emotions, which represents persons' assessment of the emotional environment in their most important relationships (3). One of those is a research by Hooley et al. that investigated the correlation between depressive symptoms and lack of emotional support, intrusiveness, irritability and criticism, as the components of perceived expression of emotions (3). This study showed that during a nine-month follow-up period, $59 \%$ of depressed patients with a high level of observed expressed emotions (based on the spousal observation) relapsed, whereas there was no recurrence of depression among those with a lower level of observed expressed emotions (3). Some studies showed that patients diagnosed with a depressive disorder had an increased neural activity when exposed to affectively negative stimuli, and a reduced activity when exposed to positive stimuli (4). Worsening of the depressive symptoms is usually caused by criticism from the family members and other relatives $(5,6)$. Difficulties in perception and recognition of emotions lead to miscommunication and may be involved in the development and maintenance of emotional disorders or complicated depressive symptoms (7).

Patients diagnosed with depression often display some form of difficulties in psychosocial functioning. This is usually manifested through a reduced social activity and may lead to problems in initiating and maintaining relationships with others (8). Numerous studies have indicated that social inadequacy and unsatisfying relationships with others play an important role in exacerbating vulnerability in depressed patients (9). Moreover, Evans et al. showed that reduced interest in leisure activities and work assignments is not confined to the early phases of the disorder, but is also present later on, as depression evolves (10).

The adequate social support reduces depressive symptoms, however, depressed individuals do not often receive enough support from their environment because their behaviour sometimes may have a negative influence on others (11). Patients with depression reported less social support, greater marital dissatisfaction, and more dysfunctional relationships than a control group in the study of Zaidi(11). Furthermore, other studies have shown that the family support is correlated with the history of suicidal behaviour in depressed patients (12).

Although some studies investigated the correlation between depression and specific problems in psychosocial functioning, level of observed expressed emotions and perceived social support, there is still a scarcity of research examining the correlation between all previously mentioned variables through one prediction model. Therefore, our research was conducted with the aim of improving understanding of the nature of depressive disorder and factors that can influence its course and outcome through investigating the potential correlations of depressive symptoms and psychosocial functioning, level of observed expressed emotions and social support available to patients diagnosed with depression.

\section{PATIENTS AND METHODS}

The research was conducted at the Clinic of Psychiatry, the Clinical Centre of Kragujevac, from January 2015 to September 2015. The study sample comprised patients diagnosed with unipolar depression: major depressive episode (F32.2) and recurrent depressive disorder (F33.2), without psychotic features. The diagnoses were made by attending psychiatrists, in accordance with the International Classification of Diseases, the 10th Revision (ICD-10) (1). Patients with manic or hypomanic episodes were excluded from the research.

The study was approved by the Ethical Committee of the Clinical Centre of Kragujevac and conducted in accordance with the Declaration of Helsinki. The goal and nature of the research were explained to the participants, who provided written informed consent. The participants completed the study measures in a single assessment session.

\section{Sample}

The study sample included 61 patients (19 men and 42 women) diagnosed with unipolar depression. The participants were between 21 to 61 years old $(\mathrm{M}=42.39, \mathrm{SD}=$ 13.387). The educational level of participants varied (primary school: $\mathrm{n}=8$; high school: $\mathrm{n}=39$; college or university: $n=14)$. The occupational status was also variable (27 participants were employed, 29 were unemployed and 5 were retired).

\section{Instruments}

The following study instruments were applied:

A short structured interview was used to obtain the data on socio-demographic characteristics (sex, age, educational level and employment), duration of disorder and the number of hospital admissions.

The Beck Depression Inventory II (BDI-II) was used to assess the presence and severity of depressive symptoms over the previous two weeks. The BDI-II is a self-report 
questionnaire consisting of 21 items aligned with the criteria for depression specified in the Diagnostic and Statistical Manual of Mental Disorders, the 4th Edition (DSM-IV) (13). Respondents estimate the presence and severity of their depressive symptoms using a four-point scale (from 0 to 3 ). The total score ( 0 to 63 ) is obtained by summing the scores for individual items; higher scores indicate greater depressive symptoms. The reliability coefficient of the questionnaire (Cronbach's alpha coefficient) ranges from .73 to .95 (14) and in our sample it was .91.

The Functioning Assessment Short Test (FAST) is a selfreport questionnaire, designed to assess the main functional problems experienced by psychiatric patients, consisting of 24 items covering autonomy, working functioning, cognitive functioning, financial problems, interpersonal relations and free time (15). Respondents indicate the severity of the problems described in each item using a four-point Likert scale (from 0 to 3 ). The total score ( 0 to 72 ) is obtained by summing the scores for individual items; higher scores indicate greater difficulties in functioning. The reliability coefficient (Cronbach's alpha coefficient) of the whole questionnaire in this sample of patients was 94 .

The Level of Expressed Emotion (LEE) is a self-report questionnaire consisting of 38 items organised into four subscales which measure patients' perceptions of the level of expressed emotion in family interactions: the lack of emotional support, intrusiveness, irritability and criticism (16). Respondents used a four-point Likert scale ( 1 to 4$)$ to indicate their level of agreement with each statement. The total score (ranging from 38 to 152) and four subscale scores were obtained by summing the scores for individual items, after recoding reverse statements. In our sample, the whole questionnaire had the reliability coefficient (Cronbach's alpha coefficient) of .91.

The Multidimensional Scale of Perceived Social Support (MSPSS) is a 12-item, self-report questionnaire in which responses are given using a seven-point Likert scale (1 to 7) (17). The statements are grouped into three subscales, representing different sources of social support: family, friends, and significant others. The overall score is the average score for all 12 statements and subscale scores are the average scores for the items making up the relevant subscale. In our sample, the reliability coefficient (Cronbach's alpha coefficient) of the whole questionnaire was .93 .

\section{Statistical analysis}

The data were analysed using SPSS v. 20.0. Descriptive statistics and reliability coefficients were calculated for all questionnaires. The correlations and hierarchical multiple regression analysis were used to verify the hypothesis of predictive values of the depressive symptoms severity, level of observed expressed emotions and perceived social support on the level of psychosocial functioning difficulties.

\section{RESULTS}

The patients reported moderate depressive symptoms and BDI-II scores were grouped around lower values (Table 1). The patients also reported a medium level of psychosocial difficulties, and moderate level of observed expressed emotions, with both scores grouped around lower values. The sample reported a high level of perceived social support, with scores largely grouped around higher values, especially for the support perceived from significant others.

Table 1. Descriptive statistics for main variables

\begin{tabular}{lcccc}
\hline & Mean & SD & Min/Max. & $\begin{array}{c}\text { skew- } \\
\text { ness }\end{array}$ \\
\hline BDI-II & 27.30 & 11.98 & $8 / 59$ & 0.558 \\
\hline FAST & 26.33 & 17.21 & $4 / 67$ & 0.871 \\
\hline LEE & 74.70 & 17.96 & $42 / 131$ & 0.763 \\
\hline $\begin{array}{l}\text { emotional } \\
\text { support }\end{array}$ & 32.61 & 10.70 & $19 / 68$ & 1.221 \\
\hline intrusiveness & 20.20 & 5.41 & $8 / 31$ & -0.024 \\
\hline irritability & 11.82 & 3.93 & $6 / 21$ & 0.404 \\
\hline criticism & 10.08 & 3.30 & $5 / 17$ & 0.419 \\
\hline MSPSS & 5.24 & 1.40 & $1 / 7$ & -0.812 \\
\hline $\begin{array}{l}\text { significant } \\
\text { others }\end{array}$ & 5.42 & 1.56 & $1 / 7$ & -1.115 \\
\hline friends & 5.17 & 1.78 & $1 / 7$ & -1.013 \\
\hline family & 5.12 & 1.75 & $1 / 7$ & 1.753 \\
\hline
\end{tabular}

The average duration of disorder was 4.64 years $(\mathrm{SD}=$ 5.128 ), and $36.1 \%$ of the participants reported that they had experienced depressive symptoms for a less than a year. The average number of hospital admissions was 2.56 and 28 patients had never been hospitalised. Women reported more severe depressive symptoms than men $\operatorname{did}(\mathrm{F}(1,55)=5.429 ; \mathrm{p}$ $<0.05)$ and were more likely to report that they had difficulty in everyday functioning $(\mathrm{MD}=12.706 ; \mathrm{F}(1,55)=4.928 ; \mathrm{p}<$ $0.05)$.

The duration of disorder and the number of hospital admissions were also in a moderate to a high positive correlation with BDI-II scores $(\mathrm{r}=0.46, \mathrm{p}<0.05 ; \mathrm{r}=0.51, \mathrm{p}<0.01$ respectively) and psychosocial functioning difficulties $(\mathrm{r}=$ $0.57, \mathrm{p}<0.01 ; \mathrm{r}=0.52, \mathrm{p}<0.01$ respectively).

The educational level was also systematically related to the level of observed expressed emotions, with college-educated patients reporting higher levels of observed expressed emotions $(\mathrm{MD}=18.585 ; \mathrm{F}(2,55)=4.861 ; \mathrm{p}<0.01)$.

The correlation between clinical and psychosocial aspects of depressive disorder

The correlations between depressive symptoms, psychosocial functioning, level of observed expressed emotion and perceived social support are shown in Table 2. All correlations were significant, except the one between the BDI-II 
scores and the level of observed expressed emotions. However, the patients who reported more depressive symptoms also reported higher levels of observed intrusiveness $(r=$ $0.29, \mathrm{p}<0.01)$ and irritability $(\mathrm{r}=0.28, \mathrm{p}<0.01)$. Similarly, the levels of perceived social support were lower when the patients perceived the lack of emotional support $(\mathrm{r}=0.533, \mathrm{p}$ $<0.01)$, higher intrusiveness $(\mathrm{r}=0.387, \mathrm{p}<0.05)$ and higher criticism $(\mathrm{r}=0.243, \mathrm{p}<0.05)$.

Table 2. Intercorrelations between the BDI-II scores, difficulties in psychosocial functioning, level of observed expressed emotion and perceived social support

\begin{tabular}{lccc}
\hline & FAST & LEE & MSPSS \\
\hline BDI-II & $.69 * *$ & .13 & $-.42^{* *}$ \\
\hline FAST & & $.31^{*}$ & $-.53^{* *}$ \\
\hline LEE & $.31 *$ & & $-.52^{* *}$ \\
\hline$* * \mathrm{p}<.01,{ }^{*} \mathrm{p}<.05$ & &
\end{tabular}

In the next section, we conducted the hierarchical multiple regression analyses in order to determine the predictive values of the depressive symptoms severity, level of observed expressed emotions and perceived social support on the psychosocial functioning difficulties. The first model includes the depressive symptoms severity, which showed the highest correlation with psychosocial functioning, afterwards perceived social support that also showed a high correlation, and finally, level of observed expressed emotions that showed a moderate correlation with the scores on FAST.

The results of linear regression analysis showed that $47.1 \%$ of the psychosocial functioning variance can be predicted by the severity of depressive symptoms $(\beta=.686, \mathrm{R} 2$ $=47.1, \mathrm{~F}(1,59)=52.58, \mathrm{p}<.001)$ as shown in Table 3 and Table 4. Including perceived social support into the model explained the additional $7 \%$ of variance, that is $54 \%$ in total of the psychosocial functioning variance $(\beta=.736, \mathrm{R} 2=54.1$, $\mathrm{F}(2,58)=34.20, \mathrm{p}<.01)$.

Table 3. Hierarchical multiple regression analysis - model summary

\begin{tabular}{|c|c|c|c|c|c|c|c|c|}
\hline \multirow{2}{*}{ Model } & \multirow{2}{*}{$\mathrm{R}$} & \multirow{2}{*}{$\mathrm{R}^{2}$} & \multirow{2}{*}{$\begin{array}{c}\text { Adjusted } \\
\mathrm{R}^{2}\end{array}$} & \multicolumn{5}{|c|}{ Change Statistics } \\
\hline & & & & $\mathrm{R}^{2}$ Change & F Change & df1 & $\mathrm{df} 2$ & Sig. F Change \\
\hline 1 & $.686^{\mathrm{a}}$ & .471 & .462 & .471 & 52.576 & 1 & 59 & .000 \\
\hline 2 & $.736^{\mathrm{b}}$ & .541 & .525 & .070 & 8.839 & 1 & 58 & .004 \\
\hline 3 & $.743^{\mathrm{c}}$ & .552 & .528 & .011 & 1.384 & 1 & 57 & .244 \\
\hline
\end{tabular}

a. Predictors: (Constant), depression

b. Predictors: (Constant), depression, social support

c. Predictors: (Constant), depression, social support, level ofobserved expressed emotions

d. Dependent variable: psychosocial functioning

Including level of observed expressed emotions into the model didn't lead to an additional explanation of the psychosocial functioning variance. The results are shown in Table 4.

Table 4. Hierarchical multiple regression analysis coefficients

\begin{tabular}{llccccc}
\hline \multirow{2}{*}{ Model } & \multicolumn{2}{c}{$\begin{array}{c}\text { Unstandardized Coef- } \\
\text { ficients }\end{array}$} & $\begin{array}{c}\text { Standardized } \\
\text { Coefficients }\end{array}$ & \multirow{2}{*}{$\mathrm{t}$} & Sig. \\
\cline { 2 - 5 } & \multicolumn{2}{c}{$\mathrm{B}$} & Std. Error & Beta & & \\
\hline \multirow{2}{*}{1} & (Constant) & -.576 & 4.047 & & -.142 & .887 \\
& depression & .986 & .136 & .686 & 7.251 & .000 \\
& (Constant) & 23.136 & 8.836 & & 2.618 & .011 \\
2 & depression & .809 & .141 & .563 & 5.739 & .000 \\
& soc. support & -3.600 & 1.211 & -.292 & -2.973 & .004 \\
& (Constant) & 9.366 & 14.647 & & .639 & .525 \\
& depression & .827 & .141 & .576 & 5.854 & .000 \\
3 & soc. support & -2.747 & 1.408 & -.223 & -1.952 & .056 \\
& obs.emotions & .118 & .100 & .123 & 1.177 & .244 \\
\hline
\end{tabular}

a. Dependent variable: psychosocial functioning 


\section{DISCUSSION}

Our results showed that the patients with more severe depressive symptoms had more problems in everyday functioning and perceived lower levels of social support. The patients with more difficulties in everyday functioning reported a higher level of perceived expressed emotions and lower levels of social support.

Depressive symptoms were shown to predict the majority of the psychosocial functioning variance $(47.1 \%)$. The previous study also found that reduced interest in leisure activities and lower task performance were not confined to the initial stages of depression, implying that depression could be a chronic disorder with much more complex consequences for patients' functioning in later phases (10). A study of over 3000 depressed subjects reported that depressive symptoms, particularly sad mood and problems with concentration, had a negative effect on psychosocial functioning (18). Persons diagnosed with depression who experience failure in performance of everyday activities become less satisfied with themselves and less prepared to face difficulties $(10,18)$. The correlation between depression and psychosocial functioning has also been confirmed by the meta-analysis of 31 clinical studies, which showed that psychotherapy improves social functioning of patients with depression (19).

Additionally, perceived social support explained 7\% of the psychosocial functioning variance $(54 \%$ in total) in our study. We found that perceived social support was negatively related to difficulties in everyday functioning and that perceived social support was an important predictor of functioning levels, which is in accordance with the results of some earlier studies (20). The lack of social support can corroborate a person's poor self-image and thus lead to impaired functioning. In our study sample, perceived social support was also in a moderate correlation with severity of depressive symptoms, which is in accordance with a large number of other studies $(21,22)$. Depressed patients report they receive less support from their social environment than persons without depressive symptoms, as well as they experience greater marital disagreement and less satisfactory relationships with people in their environment (11). Dour et al. reported that perceived social support was a risk factor for suicide attempts (23), and Bell et al. showed that $11 \%$ of the change in depressive symptoms over an 18-month period could be attributed to changes in perceived social support (24).

Although we found a moderate correlation between the level of observed expressed emotions and psychosocial functioning, LEE scores didn't lead to an additional explanation of the psychosocial functioning variance. This result might be due to a high correlation $(\mathrm{r}=.52)$ between these scores and perceived social support, since the patients who perceived a higher level of observed expressed emotions in their surroundings reported lower levels of social support too. This is also in accordance with the previous reports (25). A greater level of expressed emotions (particularly lack of emotional support, but also high intrusiveness, irritability and criticism), can lead to a greater level of social anxiety or feeling of inadequacy that may lead to poor social relations and consequently lower level of perceived social support.

\section{Limitations of the study}

Since our study showed a high positive correlation between perceived social support and level of observed expressed emotion, it's recommended to conduct the research on a larger sample using the Structural equation modeling (SEM analysis) that will assume indirect influence of level of observed expressed emotions on psychosocial functioning mediated by its correlation with perceived social support. Besides having a relative small study sample, it should be considered that we conducted the correlation study and that the conclusions about causal relations aren't possible. Finally, we used the self-reports measures that may impact the objectivity of results.

\section{CONCLUSION}

This research showed that the severity of depressive symptoms and perceived social support can predict difficulties in psychosocial functioning, while the level of observed expressed emotion was not an important predictor of psychosocial functioning. The study indicated the importance of early psychosocial interventions, psychoeducation of the patient's environment and empowering personal social skills in treating depression, in addition to the application of pharmacotherapy and individual psychotherapy.

\section{REFERENCES}

1. World Health Organization. The ICD-10 classification of mental and behavioural disorders: clinical descriptions and diagnostic guidelines. Geneva: World Health Organization; 1992.

2. Dalili MN, Penton-Voak IS, Harmer CJ, Munafò MR. Meta-analysis of emotion recognition deficits in major depressive disorder. Psychol Med. 2015; 45(6): 1135-44.

3. Hooley JM, Orley J, Teasdale JD. Levels of expressed emotion and relapse in depressed patients. Br J Psychiatr. 1986; 148(6): 642-7.

4. Stuhrmann A, Suslow T, Dannlowski U. Facial emotion processing in major depression: a systematic review of neuroimaging findings. Biol Mood Anxiety Disord. 2011; 1(1): 10 .

5. Chien WT, Chan ZC, Chan SW, Yip LK, Ip G. Psychometric properties of a Chinese version of the Level of Expressed Emotion scale and expressed emotion of family members perceived by patients with severe mental illness. Hong Kong Med J. 2016; 22(6S6): 28-34

6. Möller-Leimkühler AM, Jandl M. Expressed and perceived emotion over time: does the patients' view matter for the caregivers' burden? Eur Arch Psychiatr Clin Neurosci. 2011; 261(5): 349-55. 
7. Delle-Vigne D, Wang W, Kornreich C, Verbanck P, Campanella S. Emotional facial expression processing in depression: data from behavioural and event-related potential studies. Neurophysiol Clin. 2014; 44(2): 169-87.

8. Kupferberg A, Bicks L, Hasler G. Social functioning in major depressive disorder. Neurosci Biobehavl Rev. 2016; 69: 313-32.

9. LeMoult J, Joormann J, Sherdell L, Wright Y, Gotlib IH. Identification of emotional facial expressions following recovery from depression. J Abnorm Psychol. 2009; 118(4): 828.

10. Evans VC, Iverson GL, Yatham LN, Lam RW. The relationship between neurocognitive and psychosocial functioning in major depressive disorder: a systematic review. J Clin Psychiatr. 2014; 75(12): 1359-70.

11. Zaidi U. Gender difference in perceived social support and clinical anger in depressed patients. J Humanities Soc Sci. 2014; 19(12): 79-84

12. Bell CM, Ridley JA, Overholser JC, Young K, Athey A, Lehmann J, Phillips K. The role of perceived burden and social support in suicide and depression. Suicide Life Threat Behav. 2018; 48(1): 87-94.

13. Beck AT, Steer RA, Brown GK. Beck depression inventory-II. San Antonio. 1996; 78(2): 490-8.

14. Novović Z, Mihić LJ, Tovilović S, Jovanović V, Biro M. Psychometric characteristics of the Beck Depression Inventory on a Serbian student sample. Psihologija, 2011; 44(3):225-43.

15. Rosa AR, Sánchez-Moreno J, Martínez-Aran A, Salamero M, Torrent C, Reinares M, Comes M, Colom F, Van Riel W, Ayuso-Mateos JL, Kapczinski F. Validity and reliability of the Functioning Assessment Short Test (FAST) in bipolar disorder. Clinical Practice and Epidemiology in Mental Health. 2007; 3(1): 5.

16. Cole JD, Kazarian SS. The level of expressed emotion scale: a new measure of expressed emotion. Journal of Clinical psychology. 1988; 44(3): 392-7

17. Zimet GD, Dahlem NW, Zimet SG, Farley GK. The multidimensional scale of perceived social support. Journal of personality assessment. 1988 1; 52(1): 30-41
18. Fried EI, Nesse RM. The impact of individual depressive symptoms on impairment of psychosocial functioning. PLoS One. 2014; 9(2): e90311.

19. Renner F, Cuijpers P, Huibers MJ. The effect of psychotherapy for depression on improvements in social functioning: a meta-analysis. Psychol Med. 2014; 44(14): 2913-26.

20. Hays JC, Steffens DC, Flint EP, Bosworth HB, George LK. Does social support buffer functional decline in elderly patients with unipolar depression? Am J Psychiatr. 2001; 158(11): 1850-5.

21. iu L, Gou Z, Zuo J. Social support mediates loneliness and depression in elderly people. J Health Psychol. 2016; 21(5): 750-8.

22. Taylor RJ, Chae DH, Lincoln KD, Chatters LM. Extended family and friendship support networks are both protective and risk factors for major depressive disorder, and depressive symptoms among African Americans and Black Caribbeans. J Nerv Ment Disease. 2015; 203(2): 132.

23. Dour HJ, Wiley JF, Roy-Byrne P, Stein MB, Sullivan G, Sherbourne CD, Bystritsky A, Rose RD, Craske MG. Perceived social support mediates anxiety and depressive symptom changes following primary care intervention. Depress Anxiety. 2014; 31(5): 436-42.

24. Bell CM, Ridley JA, Overholser JC, Young K, Athey A, Lehmann J, Phillips K. The role of perceived burden and social support in suicide and depression. Suicide Life Threat Behav. 2018; 48(1): 87-94.

25. Mathew A, Prabhakaran A. Perceived expressed emotion as a risk factor for attempted suicide-A case control study. Int J Recent Trends Sci Technol. 2013. 9(2): 299302. 